\title{
Determination of Some Air Pollutants and Meteorological Parameter in Granite Dump Site in UYO LGA
}

Jonah, A. E. and Etim I. G.

Department of Science Technology, Akwa Ibom State Polytechnic Ikot Osurua, Ikot Ekpene. Nigeria.

DOI - http://doi.org/10.37502/IJSMR.2021.4510

\begin{abstract}
The determination of some air pollutant and meteorological parameter in granite dump site in Uyo L.GA was carried out using standard analytical techniques. The pollutants monitored were $\mathrm{NO}_{2}$, $\mathrm{SO}_{2}, \mathrm{H}_{2} \mathrm{~S}, \mathrm{CO}, \mathrm{NH}_{3}, \mathrm{CO}_{2}, \mathrm{Cl}_{2}, \mathrm{HCN}, \mathrm{TVOD}, \mathrm{CH}_{2} \mathrm{O}, \mathrm{PM}_{2.5}, \mathrm{PM}_{10}$, Temp, Relative Humidity (RH), Pressure and Wind Speed (WS). The results for the concentration of air pollutant and their Air Quality Index (AQI) reveals as follows $\mathrm{NO}_{2}\left(0.14 \pm 0.08(\mathrm{ppm}) ; \mathrm{AQI}=(140) . \mathrm{SO}_{2}(0.19 \pm 0.105\right.$ $(\mathrm{ppm}): \mathrm{AQI}=38) . \mathrm{H}_{2} \mathrm{~S}(0.25 \pm 0.174(\mathrm{ppm}) ; \mathrm{AQI}=125) . \mathrm{CO}(3.03 \pm 2.313(\mathrm{ppm}): \mathrm{AQI}=151.5)$ $\left.\mathrm{NH}_{3}(6.16 \pm 6.100 \mathrm{ppm}) ; \mathrm{AQI}=123.2\right) \cdot \mathrm{Cl}_{2}(0.30 \pm 0.14(\mathrm{ppm}) ; \mathrm{AQI}=300): \mathrm{HCN}(1.73 \pm 0.67$ $\left(\mathrm{mg} / \mathrm{m}^{3} ; \mathrm{AQI}=17300\right)$. TVOC $\left(0.74 \pm 0.80\left(\mathrm{mg} / \mathrm{m}^{3}\right) ; \mathrm{AQI}=148\right) . \mathrm{CH}_{2} \mathrm{O}\left(0.08 \pm 0.1002\left(\mathrm{mg} / \mathrm{m}^{3}\right) ;\right.$ $\mathrm{AQI}=666.7) . \mathrm{PM}_{2.5}\left(34.2 \pm 23.113\left(\mu \mathrm{g} / \mathrm{m}^{3}\right) ; \mathrm{AQI}=136.8\right) . \mathrm{PM}_{10}\left(78.2 \pm 81.20\left(\mu \mathrm{g} / \mathrm{m}^{3}\right) ; \mathrm{AQI}=\right.$ 156.4). Temp $\left(30.2 \pm 0.503^{0} \mathrm{C}\right)$. Relative Humidity $(\mathrm{RH}) .(76.3 \pm 1.284 \%)$. Press $(1004.1 \pm 2.73$ (kpa). W. S. (0.63 \pm 0.66 (M/S). The result should $\mathrm{NO}_{2}, \mathrm{SO}_{2}, \mathrm{SO}_{2}, \mathrm{H}_{2} \mathrm{~S}, \mathrm{CO}, \mathrm{NH}_{3}, \mathrm{Cl}_{2}, \mathrm{NH}_{3}, \mathrm{Cl}_{2}$, $\mathrm{HCN}$, and TVOC. $\mathrm{PM}_{2.5}$ and $\mathrm{PM}_{10}$ were higher than the FEPA standard limit. Correlation analyses showed that, $\mathrm{NO}_{2}$ and $\mathrm{SO}_{2}$ exhibited strong positive relationships with $\mathrm{CO}_{2}, \mathrm{NH}_{3}$, TVOC and $\mathrm{HCN}$. Hydrogen sulphide showed common source and strong correlation with $\mathrm{NH}_{3}, \mathrm{TVOC}, \mathrm{CH}_{2} \mathrm{O}$, $\mathrm{PM}_{2.5}$ and $\mathrm{PM}_{10}$ correlated positively and significantly while $\mathrm{CO}$ indicate negative correlation. Ammonia shows a strong correlation with $\mathrm{CH}_{2} \mathrm{O}$, TVOC, $\mathrm{PM}_{2.5}, \mathrm{PM}_{10}$ and $\mathrm{RH}$ at $\mathrm{P}<0.01$. Since all the investigated parameter are above the FEPA stipulated limit, there is need for regular monitoring and legislation to avoid human health risk.
\end{abstract}

Keywords: Determination, Air Pollutant, Granite, Meteorological and Parameter.

\section{Introduction}

The state of the atmosphere is of prime importance in determining the dispersal and concentration of pollutants, and their consequences. The factors responsible for pollutants dispersal in the atmosphere include: wind direction (controls where pollution is transported), wind speed (determines the rate of pollutant dispersal). Low win speed leads to higher pollutants concentration 
in local area and a higher wind speed would lead to lower concentrations over wider area (Gobo, 2014).

Globally, anthropogenic air pollutants have intensified in the atmosphere of metropolitan cities and downtown locations. It is known that air pollutants have adverse effects on human as well as the environment (Brunekreef and Holgate, 2002). Air pollution is the presence of substances in the atmosphere. The tendency for pollutants to be transported upward to higher levels or remain at ground level depend on vertical temperature distribution, which leads to the atmosphere to be either stable, unstable or in the neutral state. It is stable when there is no vertical lifting, except in the horizontal; unstable when there is turbulence which encourages mixing and hence vertical uplifting of pollutants and neutral when pollutants neither moves horizontally or vertically due to the inhibition of turbulence activities. Rocks and mineral resources cannot be extracted from the earth without some environmental impacts and high exploitation of solid minerals may lead to generation of environmental pollutants that are left behind in tailings scattered in open and partially covered pits, while some are transported by wind and flood, resulting in various environmental problems (Ogbonna et al., 2011).

The atmosphere is one of the major pathways for transport of dust contaminated with heavy metals and the major external input of bio-available metals in the environment, which are potential threats to the heath and survival of people living in proximity to granite sites (Ogbonna et al., 2018). This may be because granite atmosphere is submitted to large inputs of heavy metals arising from stationary source such as blasting of rock and large volume of tailing dust at granite site. Suspended particulate matter is quite outstanding among all pollutants emanating from granite operation. Solid materials in the form of smoke, dust and also vapour generated during granite operations are usually suspended over a long period in the air (Oguntoke et al., 2009). Air pollution causes reduction in visibility, has an adverse influence on human health, and is known to be related to global climate change (Zhu et al., 2016). Pollutants can be in the form of solid particles, liquid droplets, or gases. In addition, they may be natural or man-made. Commendations and suggestions for further studies based on the result obtained from this analysis.

\section{Materials and Methods}

\section{Study Area}

Uyo is one of the local government areas in Akwa Ibom State. Uyo is an urban area with public and private facilities such as hospitals, schools, markets, industries, motor park, government housing estates, residential houses and administrative buildings. The location chosen for the study was area with high atmospheric particulates and aerosol. The location is granite dump site in Uyo.

Equipment used in detecting the air pollutants are listed in the table below. 
168 | International Journal of Scientific and Management Research 4(5) 166-178

Table 1: Materials used in determining the air pollutants

\begin{tabular}{|c|c|}
\hline Parameters & Equipment's Model \\
\hline $\mathrm{NO}_{2}$ & $\mathrm{NO}_{2}$ gas monitor Gasman Model $19648 \mathrm{H}$ \\
\hline $\mathrm{SO}_{2}$ & $\mathrm{SO}_{2}$ gas monitor Gasman Model 19831H \\
\hline $\mathrm{H}_{2} \mathrm{~S}$ & $\mathrm{H}_{2} \mathrm{~S}$ gas monitor Gasman Model 19502H \\
\hline $\mathrm{CO}$ & CO gas monitor Gasman Model 19252H \\
\hline $\mathrm{NH}_{3}$ & $\mathrm{NH}_{3}$ gas monitor Gasman Model $1973 \mathrm{OH}$ \\
\hline $\mathrm{Cl}_{2}$ & $\mathrm{Cl}_{2}$ gas monitor Gasman Model 19812H \\
\hline $\mathrm{HCN}$ & HCN gas monitor Gasman Model 19773H \\
\hline TVOC & TVOC gas monitor Gasman Model Air Ae Steward Air quality monitor \\
\hline $\mathrm{CH}_{2} \mathrm{O}$ & $\mathrm{CH}_{2} \mathrm{O}$ gas monitor Gasman Model Air Ae Steward Air quality monitor \\
\hline $\mathrm{PM}_{2.5}$ & $\mathrm{PM}_{2.5}$ gas monitor Gasman Model Air Ae Steward Air quality monitor \\
\hline $\mathrm{PM}_{10}$ & $\mathrm{PM}_{10}$ gas monitor Gasman Model Air Ae Steward Air quality monitor \\
\hline
\end{tabular}

Other instrument was, Max/Min Thermometer (Model No: KTJTA 318) used for measuring the temperature and digital Anemometer (MASTECH MS 6252A)

\section{Determination of Air Quality Index}

Air quality index (AQI) is an overall measure of the status of a place under consideration. On the basis of air quality index "Q", the quality rating of each parameter was obtained by the formula given below (Agar-wal et al., 2008).

$\mathrm{Q}=(\mathrm{O} / \mathrm{Ps}) \mathrm{X} 100$

Where:

$\mathrm{Q} \quad=\quad$ Quality Ratings

$\mathrm{O}=$ Observed value

Ps $\quad=$ Prescribed Standards as Permissible Limit.

Subsequently, the geometric mean of this " $n$ " number of quality ratings "Q" was estimated, which is known as AQI. 
169 | International Journal of Scientific and Management Research 4(5) 166-178

\section{Results}

Figure 1: The Result of Some Air Pollutants and Meteorological Parameters in Granite Site at Uyo Local Government Area.

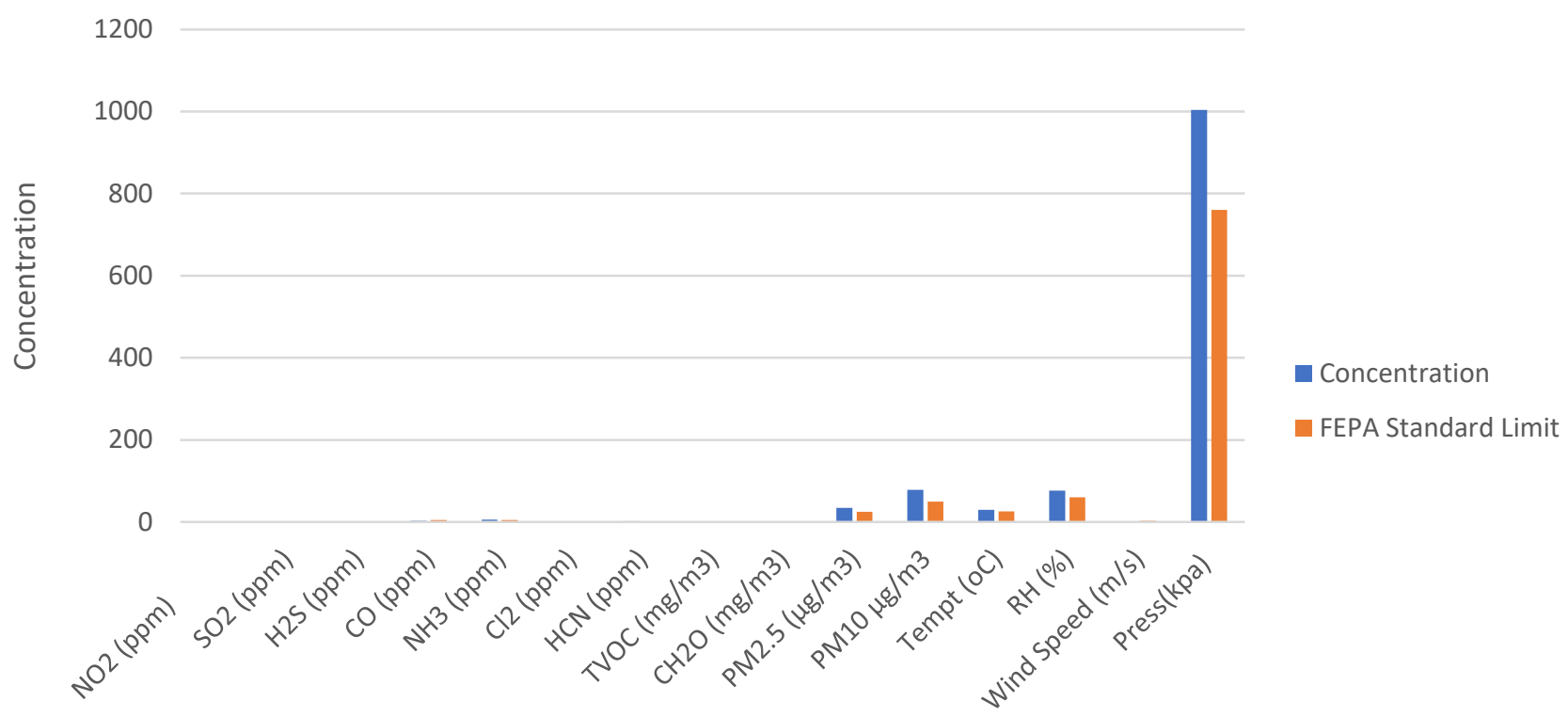

Air Quality Contaminants

Table 2: The Air Quality Index of Air Pollutants Analyzed

\begin{tabular}{ll}
\hline Air Quality Contaminant & AQI \\
\hline $\mathrm{NO}_{2}(\mathrm{ppm})$ & 140 \\
$\mathrm{SO}_{2}(\mathrm{ppm})$ & 38 \\
$\mathrm{H}_{2} \mathrm{~S}(\mathrm{ppm})$ & 125 \\
$\mathrm{CO}(\mathrm{ppm})$ & 151.5 \\
$\mathrm{NH}_{3}(\mathrm{ppm})$ & 123.2 \\
$\mathrm{Cl}_{2}(\mathrm{ppm})$ & 300 \\
$\mathrm{HCN}_{(\mathrm{ppm})}$ & 17300 \\
$\mathrm{TVOC}\left(\mathrm{mg} / \mathrm{m}^{3}\right)$ & 148 \\
$\mathrm{CH}$ & $\mathrm{O}\left(\mathrm{mg} / \mathrm{m}^{3}\right)$ \\
$\mathrm{PM}_{2.5}\left(\mu \mathrm{g} / \mathrm{m}^{3}\right)$ & 666.7 \\
$\mathrm{PM}_{10} \mu \mathrm{g} / \mathrm{m}^{3}$ & 136.8 \\
\hline
\end{tabular}

Table 3: Air quality categorizes based on the air quality index by central pollution control board (CPCB), 2009. 


\begin{tabular}{lll}
\hline S/N & AQI of Ambient Air & Prescription of Ambient Air Quality \\
\hline $\mathbf{1}$ & $<10$ & Clean \\
$\mathbf{2}$ & $10-25$ & Clean \\
$\mathbf{3}$ & $25-50$ & Fairly Clean \\
$\mathbf{4}$ & $50-75$ & Moderately Polluted \\
$\mathbf{5}$ & $75-100$ & Polluted \\
$\mathbf{6}$ & $100-125$ & Heavily Polluted \\
$\mathbf{7}$ & $>125$ & severely polluted \\
\hline
\end{tabular}

Source: CPCB (2009), AQI - Air Quality Index

\section{Discussion}

The analysis of some air pollutant and meteorological parameter at granite dump site in Uyo local government area revealed that all the analyzed air pollutants were present in the environment.

The concentration of nitrogen (iv) oxide $\left(\mathrm{NO}_{2}\right)$ was found to be $0.14 \pm 0.080 \mathrm{ppm}$, comparing, this result with the FEPA standard for $\mathrm{NO}_{2}$ 0.004-01ppm it indicates that the result was slightly on the safe limit. The mean concentration in this study is lower than $0.18 \pm 0.10 \mathrm{ppm}$ obtained by Ebong $e t$ al. (2016). A prolong inhalation of air from the study area for a long time by human may affect the lung and throat of human. Although, AQI reveal that the air is severely polluted.

Sulphur (iv) oxide $\left(\mathrm{SO}_{2}\right)$ concentration in the study recorded $0.19 \pm 0.105 \mathrm{ppm}$ which is below the standard limit of $0.05-0.5 \mathrm{ppm}$ recommended by FEPA. The evaluation of $\mathrm{SO}_{2}$ in the environment may be attributed to polluted gas emitted into the atmosphere by industrial plant or vehicles. Thus, prolong inhalation of air from the study location for a long time by human may cause respiratory problems and severe headache (Tse and Oguama, 2014). However, AQI reveals that the air is fairly polluted.

The mean concentration of hydrogen sulphide $\left(\mathrm{H}_{2} \mathrm{~S}\right)$ obtained in this study was $0.25 \pm 0.174 \mathrm{ppm}$. This value is within the range of $0.008-0.2 \mathrm{ppm}$ recommended by FEPA. The mean concentration in this study is in the range $0.32 \pm 0.16 \mathrm{ppm}$ reported by Ebong et al. (2016). Consequently, AQI reveals that the air is heavily polluted.

Carbon dioxide (CO) recorded a mean concentration of $3.03 \pm 2.313 \mathrm{ppm}$. This value is higher than the 1.0-2.0ppm recommended by the FEPA. The mean concentration in this study is lower than $31.13 \pm 8.43 \mathrm{ppm}$ reported by Ebong et al. (2016). This revealed that there is a series of anthropogenic activities carried out in the environment that may evaluate the $\mathrm{CO}$ level of the area. Prolong exposure of this elevated levels of $\mathrm{CO}$ in the study area may result in death, it can cause 
tissue damage after prolong exposure and its affinity for haemoglobin is almost 220 times greater than that of Oxygen. Although, the AQI reveals that the air is severely polluted.

Ammonia concentration $\left(\mathrm{NH}_{3}\right)$ recorded for this study is $6.16 \pm 6.10 \mathrm{ppm}$, which is higher than the standard limit of $0.2-0.5 \mathrm{ppm}$ recommended by FEPA. $\mathrm{NH}_{3}$ fall under heavily polluted when subjected into air quality standard. Consequently, the concentration of ammonia reported in this study if not controlled may cause health problems in humans, associated problems elevated $\mathrm{NH}_{3}$ in air as reported by ATSDAR (2004). The high concentration of ammonia recorded may be accredited to vehicle emission and volatilization from soil as reported by Behera et al. (2013).

The mean concentration of chlorine recorded was $0.30 \pm 0.14 \mathrm{ppm}$. Comparing this result with FEPA standard, it revealed that the result was higher than the FEPA stipulated standard of $0.03-$

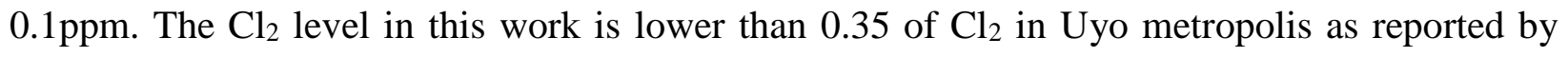
Ebong et al. (2016). However, the AQI reveals that the air is severely polluted.

Hydrogen Cyanide $(\mathrm{HCN})$ recorded a mean concentration of $1.73 \pm 0.67 \mathrm{ppm}$. The value in this study is higher than $0.01 \mathrm{ppm}$ the stipulated standard of FEPA. The present of HCN in the study area may be attributed to emission of gas into the atmosphere by burning of chemicals containing materials. Although study shows that exposure to hydrogen cyanide at levels less than 10ppm will protect the workers from significant risk of headache, weakness, and nervousness, which together constitute materials impairment of health; this effect has been observed in individuals exposed at 10ppm level over a full working shift. Consequently, the AQI reveals that the air is severely polluted.

The mean concentration of Total Volatile Organic Compound obtained in this study is $0.74 \pm 0.80 \mathrm{mg} / \mathrm{m}^{3}$. This value is above the standard limit of $0.33-0.5 \mathrm{mg} / \mathrm{m}^{3}$ recommended by FEPA. High level of TVOC can cause health effect such as eye, noise and throat irritation, headache, loss of coordination, nausea and damage to the liver, kidney and central nervous system. The presence of TVOC in the study area may be as a result of industrial activities in the study area. Formaldehyde $\left(\mathrm{CH}_{2} \mathrm{O}\right)$ recorded a mean concentration of $0.08 \pm 0.100 \mathrm{mg} / \mathrm{m}^{3}$ compared with the standard limit of $0.012 \mathrm{mg} / \mathrm{m}^{3}$ recommended by FEPA. The present of $\mathrm{CH}_{2} \mathrm{O}$ in the study area may be as a result of vertical exhaust gas emitted into the atmosphere. Thus, the high level of formaldehyde can enter the blood if inhale. Formaldehydes levels when exceed the normal concentration may be carcinogenic to the habitat, according to the Department of Health and Human Services (DHHS) and the International Agency for Research on Cancer (IARC). Consequently, the AQI reveals that the air is severely polluted.

The mean concentration of $\mathrm{PM}_{2.5} 34.2 \pm 23 \mu \mathrm{g} / \mathrm{m}^{3}$ was higher than the stipulated value of $25 \mu \mathrm{g} / \mathrm{m}^{3}$ recommended by FEPA. The mean concentration in this work is higher than $15.20 \pm 12.0 \mu \mathrm{g} / \mathrm{m}^{3}$ revealed by Gupta et al. (2006). A study published in the Journal of the American Medical Association suggests that long-term exposure to $\mathrm{PM}_{2.5}$ may lead to plaque deposits in arteries, 
causing vascular inflammation and a hardening of the arteries which can eventually lead to heart attack and stroke. Consequently, the AQI reveals that the air is severely polluted.

$\mathrm{PM}_{10}$ in the study area is $78.2 \pm 81.20 \mu \mathrm{g} / \mathrm{m}^{3}$ which is above the standard limit of $50 \mu \mathrm{g} / \mathrm{m}^{3}$ recommended by FEPA. The mean concentration in this work is higher than $46.00 \mu \mathrm{g} / \mathrm{m}^{3}$ reveal by Jonathan et al. (2002). Exposure to high concentrations of $\mathrm{PM}_{10}$ can result in a number of health impacts which may lead to acute cardiovascular disease, chronic obstruction, pulmonary and lung cancer (Kan and Chen, 2004). The AQI reveals that the air is severely polluted.

The temperature in the study area was found to be $30.2 \pm 0.50^{\circ} \mathrm{C}$. This result is higher than the FEPA stipulated standard for temperature $26.4^{\circ} \mathrm{C}$. This indicates that the activities carried out in the area increase the temperature level of the area. High temperature in the environment may lead to series of health effect (Anderson, 2005). Like heat cramps, heat stroke or even death.

The relative humidity of the study area was $76.3 \pm 1.30 \%$ which is higher than FEPA stipulated standard of $25-60 \%$. High level of relative humidity in the area may be attributed to series of industrial activities in the area and other human activities in the environment. High relative humidity in the environment may affect the habitat, it can lead to heatstroke, and heat cramps.

Pressure level of the study area was $1004.1 \pm 2.73 \mathrm{kpa}$ which is higher than the FEPA recommended standard limit of $769 \mathrm{kpa}$. The high pressure in the area may still be attributed to human activities in the area. The pressure level may be harmful to the habitat. 
173 | International Journal of Scientific and Management Research 4(5) 166-178

TABLE 4: correlation of gaseous pollutants with some meteorological parameter

$\mathrm{NO}_{2}$

$\mathrm{SO}_{2} \quad \mathrm{H}_{2} \mathrm{~S}$

$\mathrm{CO} \quad \mathrm{CO}_{2}$

$\mathrm{NH}_{3}$

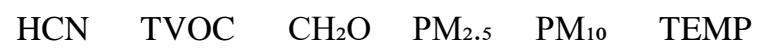

PRESS

WS

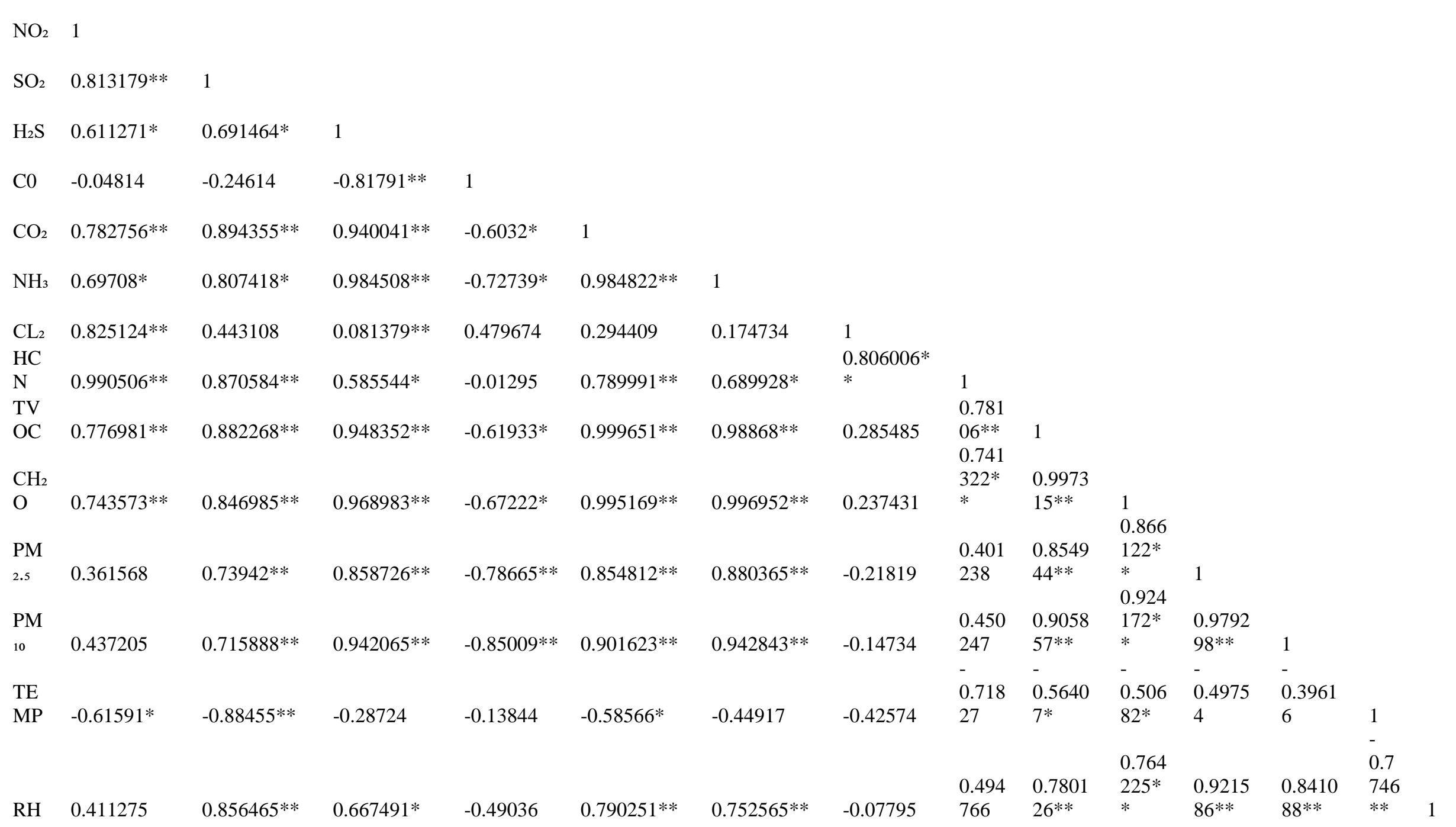

Copyright (C IJSMR 2021, All right reserved (www.ijsmr.in) 
174 | International Journal of Scientific and Management Research 4(5) 166-178

PR

ESS

WS

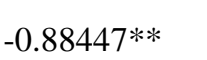

$-0.28702$

$-0.13875$

$-0.5855^{*}$

$\begin{array}{ll}-0.44897 & -0.42599 \\ -0.18423 & -0.40349\end{array}$

$\overline{0} 718 \quad \overline{0} \mathbf{0} 639$

$33 * * \quad *$

*

0.506

$506-0.4972$

$64 *$

5

8

$0.569-0.3133$

$-0.37239$

$-0.18423$

$-0.40349$

$-0.72186 * * \quad-0.01121$

0.3958

608

$41 * \quad 0.6 \quad 0.9609 *$

** Correlation is significant at the 0.01 level ( 2 tailed)

* Correlation is significant at the 0.05 level ( 2 tailed) 
175 | International Journal of Scientific and Management Research 4(5) 166-178

\section{Correlation Analysis}

The correlation analysis conducted as shown in table 4.3 revealed a strong relationship among air pollutants studied.

$\mathrm{HNO} 2$ showed a strong positive correlation between $\mathrm{SO} 2, \mathrm{CO} 2, \mathrm{Cl} 2, \mathrm{HCN}, \mathrm{TVOC}$ and $\mathrm{CH} 2 \mathrm{O}$ at 0.01 with $(\mathrm{r}=0.813179,0.782756,0.825124,0.990306,0.776981$ and 0.743373 respectively) and 0.05 limit of with $\mathrm{H} 2 \mathrm{~S}, \mathrm{NH} 3(\mathrm{r}=0.611271,0.69708)$. However, there was a negative correlation between NO2 with Temp and Press at 0.05 level with (-0.61591 and 0.61597 respectively). This shows that the source of NO2 may have also contributed to the concentration of $\mathrm{H} 2 \mathrm{~S}$ and NH3. This shows a direct relationship among the studied air pollutions. According to Huang et al., (2008) all the correlation coefficient indicates potential health effect.

$\mathrm{SO} 2$ correlated strong positively with $\mathrm{CO} 2, \mathrm{NH} 3, \mathrm{HCN}$, TVOD, CH2O PM2.5, PM10 and RH at 0.01 level with $(\mathrm{r}=0.894355,0.807418,0.870584,0.882268,0.846985,0.73942$. 0.73942, 0.715888 and 0.856465 respectively) and strongly but negatively with Temp, Press and WS at 0.01 level with $(\mathrm{r}=-0.88455,-0.88447$ and -0.72186$)$. This indicate that as Temp, Press and WS increases $\mathrm{SO} 2$ decreases and vice versa.

Hydrogen sulphide showed a strong positive correlation relationship with CO2, NH3, TVOC, $\mathrm{CH} 2 \mathrm{O}, \mathrm{PM} 2.5$ and PM10 at 0.01 level with $(\mathrm{r}=0.940041,0.0984508,0948352,0.968903$, 0.858726 and 0.942065 respectively) and also a strong negative correlation with $\mathrm{CO}(\mathrm{r}=-0.81791$ at 0.01 level. As reported by Romic and Romic, (2002) H2S may have been produced from the same source as $\mathrm{CO} 2, \mathrm{NH} 3$, and others in areas investigated thus, an increment in the concentration $\mathrm{H} 2 \mathrm{~S}$ may result in a corresponding increment in concentrations of these air pollutants and vice versa.

Correlation analysis between carbon (II) oxide (CO) and other air pollutant revealed a strong negative relationship for CO-NH3, CO-PM2.5 and CO-PM10 at 0.01 confidence limit with $(\mathrm{r}=$ $0.72737,-0.78665$ and -0.85009 respectively). And at 0.05 confidence limit there was a negative correlation with $\mathrm{CO}-\mathrm{CO} 2, \mathrm{CO}-\mathrm{TVOC}, \mathrm{CO}-\mathrm{CH} 2 \mathrm{O}$ with $(\mathrm{r}=-0.6032,-0.61933$ and -0.67222$)$ this result shows that as $\mathrm{CO}$ increases the level of $\mathrm{NH} 3$ decreases and vice versa.

Correlation analysis between ammonia (NH3) and other air pollutants studied revealed that there was a linear relationship between NH3-CH2O, NH3-TVOC, NH3-PM2.5, PM10 and RH at 0.01 level with $(\mathrm{r}=0.996952,0.98868,0.880365,0.942843$ and 0.752565$)$ respectively and also correlated with $\mathrm{HCN}$ at 0.05 level with $(\mathrm{r}=0.689928)$. Continuous exposure to $\mathrm{NH} 3$ indicate potential health effect (ATSDR) like burning of the eyes, nose, throat and respiratory tract and can result in blindness.

TVOC showed a strong positive correlation with PM2.5, CH2O, PM10 and RH at 0.01 level with ( $\mathrm{r}=0.854944,0.99315,0.905857$ and 0.780126 respectively). Also, correlation negatively with Temp and Press at 0.05 level with $(r=0.56407$ and -0.5639$)$. This shows that, as the concentration of TVOC increases that of Temp and Pressure decreases.

Formaldehydes $(\mathrm{CH} 2 \mathrm{O})$ showed a strong positive correlation with PM2.5, PM10 and RH at 0.01 level with $(\mathrm{r}=0.866122,0.924172$ and 0.764225$)$. This shows that PM2.5 and PM10 may have also contributed significant concentrations to the source of $\mathrm{CH} 2 \mathrm{O}$ in the air of the environment 
studied. Result also indicated that $\mathrm{CH} 2 \mathrm{O}$ correlated negatively with Temp and Press at 0.05 level with $(r=-0.50682$ and -0.50664$)$. These indicated that as $\mathrm{CH} 2 \mathrm{O}$ decreases temp. and Press increases and vice versa.

PM2.5 showed a strong and positive correlation with PM10 and RH at 0.05 level with $(\mathrm{r}=$ 0.979298 and 0.921586 ). This shows that PM10 may have emanated from a similar source with PM2.5 within the study area.

PM10 showed a strong positive correlation with $\mathrm{RH}$ at 0.06 level with $(\mathrm{r}=0.841088)$, this indicates that RH may have contributed significant to the concentration of PM10 in the air of the environment.

Temperature showed a positive correlation with WS at 0.05 level with $(r=0.960841)$ and also a negative correlation with RH at 0.05 level with $(r=-0.7746)$. This result indicates that as the temperature increases $\mathrm{RH}$ decreases and vice versa.

\section{Conclusion}

This research work conducted to determine some air pollutant and meteorological parameters in granite site in Uyo L.G.A. has identified that, the air environment has been seriously affected by granite dust and other commercial activities within the area. The study has shown that the level of sulphur dioxide, falls under faily clean air while hydrogen cyanide and Ammonia and fall under heavily polluted air. The study has also shown that Nitrogen (IV) oxide, carbon oxide, chlorine, Total Volatile Organic Compound (TVOC), Formaldehyde $\left(\mathrm{CH}_{2} \mathrm{O}\right)$, particulate matter $\left(\mathrm{PM}_{2.5}\right.$ and $\mathrm{PM}_{10}$ ), presence in the study area call for concern as it will lead to possible health implications. Factors such as exhaust air from vehicles, heat from vehicles engines and dust from the study area as the major sources of these air contaminants/pollutants in area under investigation. Urgent control measures are needed in this environment as these pollutions are threat to human health. Air particulates from similar sources were also identified using correlation analysis.

\section{Recommendations}

Based on the outcome of this research work the following recommendations have been made:

i. Awareness should be created to sensitive residents of the study area on the potential health risk associated with the inhalation of air pollutant like $\mathrm{NO}, \mathrm{CO}, \mathrm{Cl}_{2}, \mathrm{TVOC}, \mathrm{CH}_{2} \mathrm{O}, \mathrm{PM}_{2.5}$ and $\mathrm{PM}_{10}$.

ii. Dust controls should be used, dust control can be as simple as a water hose to wet the dust before it becomes airborne.

iii. Using equipment that provides water to the tools that is being used.

iv.Minimize exposures to nearby workers by using good work practices, such as wearing disposable or washable protective clothes at the worksite. 
v. Shower if possible and change into clean clothes before leaving the worksite to prevent contamination of cars, homes, and other work areas.

vi.Government should conduct air monitoring to measure worker exposures and ensure that control is provided adequately for workers and people leaving around the study area.

\section{References}

1) Agency for Toxic Substance and Disease Registry (ATSDR) (2004). Toxicological profile for Ammonia. U. S. Department of Health and Human Services, Public Health Services. CAS 7664, 41-7. P. 2.

2) Anderson, Z. J., Kristiansen, L. C., Andersen, K. K., Olsen, T. S., Hvidberg, M., Jensen, S. S. \& Raaschov, N. O. (2005). Stroke and long-term exposure to outdoor air pollution from nitrogen dioxide: A cohort study. Stroke, 43(2), 320 - 325.

3) Agarwal, S., Swami, I. B. \& Gupta, A. B.(2008). Interpretation of ambient air and Air Quality Parameters in Jaipur City - A case study. Nature Environment and pollution Technology.7 (4), 573-578

4) Behera, S. N., Sharma, M., Aneja, V. P. \& Balascubramanian, R. (2013). Ammonia in the atmosphere; A review on emission sources, atmospheric chemistry and deposition on terrestrial bodies. Environ. Sci. Pollut. Res. Int., 20(11), $8092-8131$.

5) Brunekreef, B. \& Holgate, S. T. (2002). Air pollution and health. The Lancet, 360, 1233 1242.

6) CPCB (2009). Standards for liquid equivalent gaseous emission Automobile Exhaust, Noise and Ambient Quality Pollutant control and law series: Ministry of Environment and forests Government of India, New Delhi 2005-2009.

7) Chen, T. M., Gokhale, J., Shofer, S. \& Kuschner, W. G. (2007). Outdoor air pollution: nitrogen dioxide, sulfur dioxide and carbon monoxide health effect. American Journal of the Medical Science, 333(4), 249 - 256.

8) Ebong, G. A. \& Mkpenie, V. (2016). Air quality monitoring in Uyo metropolis, Akwa Ibom State. Niger Delta region of Nigeria. International Journal of Scientific Research in Environmental Science, 4(2), 55 -62.

9) Gobo, A. E. \& Abam, T. K. (2002). Analysis of some meteorological parameters pertinent to air pollution in Okrika-Onne axis of Rivers State, Nigeria. African Journal of Environmental Pollution and Health, 1(1): 64 - 71.

10) Gobo, A. E. (2014). Mainstreaming climate change adaptation and mitigation issues into development, planning in Rivers State. US Open Climate Change Journal, 1(1): 1 - 11.

11) Gupta, I. \& Kumor, R. (2006). Trends of particulate matter in four cities in India. Atmospheric Environment, 40, 2552 - 2566.

12) Huang, C. Weihao, M. and Philip, K. (2008). " $\mathrm{H}_{2} \mathrm{~S}$ Synthesizing Enzymes Biochemistry and Molecular Aspect; Chemistry. Biochemistry and Pharmacology of Hydrogen Sulfide" Springer International Publicshing. 230. Pp. 3-25. 
13) International Agency for Research on Cancer (IARC) (2006). Monographs on the evaluation of Carcinogenic risk to humans, 88, Lyon France, Pp. 39 - 45.

14) Jonathan, M., Sament, M. D., Francesca, D., Frank, C. \& Curriero, W. C. (2000). Tone, particulate air pollution and mortality in 20 US cities. The New Journal of Medicine, 343, $1742-1749$.

15) Kan, H. \& Chen, B. (2004). Particulate air pollution in urban areas of Shanghai, Chai: Health-based economic assessment. Science of the Total Environment, 322, 71 - 79.

16) Ogbonna, P. C., Emea, R. \& Teixera da Silva, J. A. (2011). Heavy metal concentration in soil and woody plant in a quarry. Toxicology and Environmental Chemistry, 93(5), 895 903.

17) Ogbonna, P. C., Kalu, E. N. \& Nwankwo, O. U. (2018). Determination of particulate matter. Nigeria Journal of Environmental Science and Technology, 2(2), 160 - 170.

18) Oguntoke, O., Aboaba, A. \& Gbadebo, T. A. (2009). Impact of granite quarrying on the health of workers and nearby residents in Abeokuta, Ogun State, Nigeria. Ethiopian Journal of Environmental Studies and Management, 2(1), 171 - 178.

19) Rogula-Kozlowska, W., Klejnowski, K. \& Rogula-Kopiec, P. (2012). A study on the seasonal mass closure of ambient fine and coarse dusts in Zabize, Poland. Bull. Environ. Contam. Toxicol, 88, $722-729$.

20) Romic, M. \& Romic, D. (2002). Heavy metal distributionin agricultural top soil in urban areas. Environ. Geol. 43:795-805.

21) Tse, A. C. \& Oguama, A. C. (2014). Air quality in parts of the University of Port Harcourt, Rivers State. Scientific Africana, 13(1), 120 - 137.

22) United State Environmental Protection Agency (2019). Table of historical $\mathrm{SO}_{2} \mathrm{NAAQS}$, sulfur USEPA. http://www.3epa.gov. 28 January, 2020.

23) WHO Regional Office of Europe (2000). Air pollution and its effects on human health. Med. Journal, 5(1), $71-79$.

24) Zhu, I., Liu, J., Cong, L., Ma, W. \& Ma, W. (2016). Spatiotemporal characteristic of particulate matter and dry deposition flux in the Cuihu Wetland in Beijing, 11(7), $1-16$.

\section{Works Cited}

[1] Jonah, A. E. and Etim I. G, "Determination of Some Air Pollutants and Meteorological Parameter in Granite Dump Site in UYO LGA," International Journal of Scientific and Management Research, vol. 04, no. 05, pp. 166-178, 2021. 